\title{
ROLE OF OCULAR ANGIOGENIC FACTORS IN THE DEVELOPMENT OF NEOVASCULAR AGE-RELATED MACULAR DEGENERATION
}

\author{
Elīza Briede ${ }^{1,2, \#}$, Kristīne Baumane ${ }^{1,2}$, and Angelika Krūmiṇa ${ }^{1,3}$ \\ ${ }^{1}$ Rīga East University Hospital, 2 Hipokrata Str., Rīga, LV-1082, LATVIA \\ ${ }^{2}$ Residency Development Programme, University of Latvia, 19 Raina Blvd., Rīga, LV-1050, LATVIA \\ ${ }^{3}$ Department of Infectology, Rīga Stradiṇš University, 16 Dzirciema Str., Rīga, LV-1007, LATVIA \\ \# Corresponding author, elbriede@gmail.com
}

Communicated by Aija Žileviča

\begin{abstract}
Age-related macular degeneration $(A M D)$ is a progressive degenerative eye disease. Neovascular age-related macular degeneration (nAMD) is the advanced form of AMD characterised by abnormal growth of newly formed blood vessels in chorioidea which typically involves fluid accumulation in the retina or retinal haemorrhage, retinal epithelial detachments, hard exudate or subretinal scars. The process of angiogenesis is controlled by ocular angiogenic factors, which have enabled the development of different treatment options aimed at these factors. This review aims to compile the available information about the most commonly identified ocular angiogenic factors, uncovering their role in the pathogenesis of nAMD and assessing their application possibilities as biomarkers of disease identification and treatment.
\end{abstract}

Key words: angiogenic factors, biomarkers, vascular endothelial growth factor, pigment epithelium-derived factor.

\section{INTRODUCTION}

Age-related macular degeneration (AMD) is a progressive degenerative disease of the retina, in which the macula is affected. The prevalence of the disease increases with age, and it is the predominant cause of blindness in developed countries, accounting for $8.7 \%$ of all blindness worldwide (Evans et al., 2004; van Lookeren Campagne et al., 2014; Wong et al., 2014). It has been estimated that in 2040, there will be 288 million people affected by AMD in the world. When simulating different AMD models, it has been assessed that the prevalence of AMD will gradually increase with existing medical treatment being able to lower approximately $35 \%$ of visual impairment in the future (Rein $e t$ al., 2009; Wong et al., 2014).

There have been purposed many classification systems for AMD. AMD can be classified as early, intermediate, and late. Early AMD is manifested by pigmentary irregularities of the retina and deposition of drusen, which can be classified as small ( $63 \mu \mathrm{m}$ or less), intermediate $(>63 \mu \mathrm{m}<125$ $\mu \mathrm{m})$ and large $(\geq 125 \mu \mathrm{m})$. Intermediate AMD is character- ised by extensive collections of intermediate and large size drusen. Late AMD is defined as neovascular AMD (nAMD) or geographic atrophy. A more detailed classification has been purposed by the Age-Related Eye Disease Study (AREDS), dividing AMD into five subcategories involving the amount, size and nature of drusen, localisation, and area of geographic atrophy and neovascularisation (Lambert et al., 2016).

Early symptoms of AMD involve distorted vision during everyday activities and a dark patch in the central vision. nAMD is usually characterised by choroidal neovascularisation, which typically involves fluid accumulation in the retina or retinal haemorrhage, retinal epithelial detachments, hard exudate or subretinal scars. Geographic atrophy includes outer retinal thinning (Mitchell et al., 2018).

In recent years, there has been an increasing interest in biomarkers for nAMD. A biomarker has been defined as a characteristics that is objectively measured and evaluated as an indicator of normal biological processes, pathogenic processes, or pharmacologic responses to a therapeutic inter- 
vention (Anonymous, 2001). The main target for the validation of biomarkers in the case of AMD is screening and diagnostic assays for early disease detection. Information provided by biomarkers can also be used for assessment of the response to the applicated treatment, and to evaluate the efficacy of therapy (Lambert et al., 2016).

In recent years, many possible systemic and ocular biomarkers have been identified, which could help to assess the individual risk for the development of the disease and could be used to monitor the course of nAMD when the disease has been already diagnosed and treated. Categorising biomarkers in specific groups could help to better understand the possibilities of their applicability. The latest research stresses that, in addition to the detection of single biomarkers, a complex of biomarkers should be used to improve the specificity and predictive value of biomarkers in the case of AMD (Kersten et al., 2018).

This review aims to compile the available information about the most commonly identified ocular angiogenic factors, uncovering their role in the pathogenesis of nAMD and assessing their application possibilities as biomarkers of disease identification and treatment process.

\section{RISK FACTORS FOR AMD}

AMD has been associated with many risk factors, which have an essential role in the development of the disease. Age has been estimated as the most important risk factor. A population-based study of 42080 individuals showed prevalence of early AMD to be $3.5 \%$ in the 55-59 age group and $17.6 \%$ for patients older than 85 years of age. The prevalence of late AMD increased from almost zero in the younger age group to $9.8 \%$ in patients older than 85 years (Colijn et al., 2017; Mitchell et al., 2018).

It has been shown that nAMD has higher prevalence in whites when compared to blacks (Clemons et al., 2005). European white people have a higher risk for AMD than other races. When compared to the Asian population, Europeans have almost two-times higher prevalence for any AMD (12.3\% and $7.4 \%$, respectively). The difference in prevalence between Europeans and African people is $12.3 \%$ and $7.5 \%$, respectively (Mitchell et al., 2018).

There have been different results on whether gender is a certain risk factor for AMD. Some studies indicate that there is a slightly higher risk for women to develop nAMD (Owen et al., 2012; Grassmann et al., 2015).

Smoking and obesity are the most important modifiable risk factors. It has been shown that smoking increases the risk for AMD development by two-to-three times and has a strong correlation with development of nAMD. Obesity and dietary fat intake are positively correlated with the incidence and progression of AMD (Lambert et al., 2016). Family history, reduced intake of antioxidants and omega-3 fatty acids, and reduced physical activity have been reported to increase the risk of the development of AMD (Kersten et al., 2018).

An association between AMD and cardiovascular diseases (CVD) has been established. It has been suggested that there is an increased risk for patients with hypertension to develop AMD. A genetic relationship has been found between AMD and CVD, which possibly indicates that CVD may also be the underlying systemic disease for the development of AMD (Lambert et al., 2016; Rastogi et al., 2016).

\section{ROLE OF ANGIOGENIC FACTORS IN THE PATHO- GENESIS OF nAMD}

The pathogenesis of nAMD is a complex mechanism that is not yet fully understood. Hypoxia, oxidative stress, retinal pigment epithelium (RPE) inflammation, and loss of choriocapillaris with resulting reduction of blood supply causes metabolic distress, causing RPE and retina to produce different angiogenic factors, initiating the development of choroidal neovascularisation ( $\mathrm{Ng}$ and Adamis, 2005; Kim et al., 2019). The process of angiogenesis is controlled by proangiogenic and antiangiogenic factors, which are secreted by various cells such as endothelial cells, fibroblasts, smooth muscle cells, platelets, inflammatory cells, and cancer cells. Angiogenic factors work through different mechanisms, consequently promoting the formation of tubular structures, stabilisation, and maturation of the new blood vessels, recruiting various cells, and producing extracellular matrix.

Angiogenic factors have enabled the development of different treatment options targeted on these factors. In recent years, considering the importance of angiogenic factors in the pathogenesis of nAMD, their role as possible biomarkers of the disease has been studied extensively ( $\mathrm{Ng}$ and Adamis 2005; Kersten et al., 2018; Fallah et al., 2019).

\section{ANGIOGENIC FACTORS IN nAMD}

Vascular endothelial growth factor. Vascular endothelial growth factor (VEGF) is an angiogenic factor that has been identified as an important catalyst for the development and maintenance of ocular neovascularisation induced by hypoxia (Kersten et al., 2018; Tamhane et al., 2019). There are five members of identified human VEGF — VEGF A, VEGF B, VEGF C, VEGF D, and placental growth factor (PIGF). VEGF in normal levels tends to maintain a healthy state of the retina. Signals of hypoxia and inflammation stimulate VEGF, which promotes angiogenesis, causing endothelial cell migration and proliferation, forming new blood vessels that are fragile and cause microvascular leakage, which further intensifies ischemia due to poor tissue perfusion, and even more, increasing VEGF levels (Storkebaum and Carmeliet, 2004; Kinnunen et al., 2012). It has been established that VEGF promotes the formation of CNV membranes (Berg et al., 2015). 
Many studies have shown that VEGF can be found at elevated levels in the aqueous humour. In a study conducted by Tong et al., it was found that VEGF levels in aqueous humour in eyes with AMD were significantly higher when compared to a control group $(668.9 \mathrm{pg} / \mathrm{ml}$ and $108.3 \mathrm{pg} / \mathrm{ml}$, respectively) (Tong et al., 2006). A statistically significant association between VEGF gene polymorphisms (+674 and +936) and nAMD has been found, indicating that early detection of the VEGF gene could improve management strategies for patients at risk (Gupta et al., 2014; Bakri et al., 2018). Concentration of soluble VEGF receptor (sVEGFR) has been found to be significantly higher in nAMD when compared to control patients $(p=0.005)(\mathrm{Hu}-$ ber and Wachtlin, 2012). Although studies indicate that VEGF is strongly associated with nAMD and that it can be detected in elevated levels in aqueous humour, there have been some studies where such an association was not found. In a study performed by Balne et al., the VEGF level in aqueous humour did not significantly differ between AMD patients and the control group (Balne et al., 2018). Opinion about the significance of the VEGF level in blood plasma differs. In several studies, the VEGF level in blood plasma was significantly elevated when compared to the control group (Tsai et al., 2006), but mostly it has been reported that there is no significant association between the VEGF level in blood plasma and nAMD (Gu et al., 2014; Zehetner et al., 2014; Ioanna et al., 2018).

Placental growth factor. Placental growth factor (PGF) is a pleiotropic factor with a primary function to regulate the growth and maturation of blood vessels, and therefore, it is considered to be a proangiogenic factor. Regulation is carried out by recruiting different cells that release angiogenic and lymphangiogenic factors to initiate the formation of new blood vessels (Mesquita et al., 2018). PGF has been found in aqueous humour, vitreous, and retina, and it has been found that inhibition of PGF reduces neovascularisation, retinal leakage, and inflammation (Van Bergen et al., 2019).

Two PGF single nucleotide polymorphisms (SNPs) (rs2268615, rs2268614) are associated with nAMD, and the PIGF gene can be assumed to be a susceptibility gene (Chen et al., 2016). It was shown that PGF inhibition significantly reduced the incidence and the severity of laser-induced choroidal neovascularisation when compared to control animals (Rakic et al., 2003). It has been observed that PGF in collaboration with VEGF-A significantly reduces neovascularisation, suggesting that the inhibition of PIGF intensifies the effect obtained from inhibition of VEGF-A (Huo et al., 2015). PGF levels in blood plasma have been found to be higher in patients with nAMD, but further investigation is necessary to evaluate the significance of the plasma PGF levels (Ioanna et al., 2018).

Insulin-like growth factor-1. Insulin-like growth factor-1 (IGF-1) promotes endothelial cell proliferation and also acts on retinal pigment epithelial (RPE) cells. IGF-1 induces the synthesis and secretion of VEGF from RPE cells, which further promotes angiogenesis of the adjacent choriocapil- laris resulting in choroidal neovascularisation (Rosenthal et al., 2004). Inhibition of IGF-1 signals causes a reduction in levels of VEGF, implying that IGF-1 is involved in the pathogenesis of AMD (Sall et al., 2004). A significant association between SNP rs2872060 in IGF-1 receptor and AMD was shown, suggesting higher risk for the development of nAMD (Chiu et al., 2011). A significantly higher level of IGF-1 in blood plasma was found for patients with nAMD and intermediate AMD (Castellino et al., 2018). The studies performed thus far suggest that IGF-1 is involved in the progression to advanced AMD stage, and more research should be conducted in this direction.

Platelet derived growth factor. Platelet derived growth factor (PDGF) is from endothelial cells, macrophages, epithelial cells and is present in platelets. There are five biologically active forms - homodimers PDGF-A, PDGF-B, PDGF-C, PDGF-D, and heterodimer PDGF-AB. PDGF is important for vascular stability by recruiting pericytes. PDGF is involved in the pathogenesis of retinal vasculopathies. It has been observed that vessel coating with pericytes decreases susceptibility of newly formed blood vessels for anti-VEGF therapy, and therefore, inhibition of PDGF possibly reduces the progression of neovascularisation (Betsholtz, 2004; Zehetner et al., 2014; Kazlauskas, 2017). Concentration of PDGF-B was observed to be almost four times higher in blood plasma than in the control group (Zehetner et al., 2014). In recent years, a combination therapy with anti-PDGF and anti-VEGF has demonstrated better results in safety and efficacy than anti-VEGF monotherapy for the treatment of nAMD (Jaffe et al., 2017). The available evidence suggests that PDGF is involved in the pathogenesis and progression of nAMD, although further investigation of PDGF is necessary.

Angiopoietin 1, Angiopoietin 2. Angiopoietin 1 and 2 (Ang1, Ang2) are ligands for endothelial cell receptor Tie2. Ang1 plays an essential role in the recruitment of pericytes, stabilising newly formed blood vessels, and acts as an agonist causing the phosphorylation of Tie 2 receptor. Ang2 acts as an antagonist and inhibits Ang1-initiated phosphorylation and destabilises the endothelial cell layer of newly formed blood vessels, improving sensitivity for proangiogenic factors, especially VEGF. Ang1 and Ang2 have been identified in human CNV membranes (Ng and Adamis, 2005; Chakravarthy et al., 2017). Significantly higher levels of Ang2 in the aqueous humour were obtained in patients with nAMD when compared to a control group, and it was concluded that the level of Ang2 was correlated with the severity of the disease ( $\mathrm{Ng}$ et al., 2017). Ang1 has been associated with a significant suppression in the level of VEGF and a reduction of neovascularisation in animals. It has been purposed that Ang1-induced Tie2 receptor activation promotes the formation of healthy choriocapillaris, promoting tissue regeneration, and therefore Ang2 inhibition is considered as a promising treatment alternative (Lambert et al., 2016; Kim et al., 2019). A novel bispecific antibody that consists of both anti-VEGF/angiopoietin II has been shown to improve the anatomical state of the retina, and visual acuity, and fur- 
ther investigation if this is in progress (Chakravarthy et al., 2017). A statistically significant increase of the Ang2 level was detected in aqueous humour after treatment with intravitreal bevacizumab, purposing that Ang2 should be considered as a biomarker and a new treatment target (Cabral et al., 2018). Ang1 and Ang2 can be considered to be antagonistic of each other, and therefore, significant alterations in the level of both angiogenic factors could induce the progression of nAMD.

Transforming growth factor beta. Transforming growth factor beta (TGF- $\beta$ ) is a proangiogenic factor that induces the production of extracellular matrix and VEGF and provides the appropriate interactions between endothelial cells and pericytes. In the endothelial cells, TGF- $\beta$ is bound to ALK1 and ALK5 receptors, which further activates two different signal pathways of angiogenesis opposite to each other. ALK1 promotes the formation of new blood vessels while ALK5 aims to maintain the integrity of mature blood vessels. It is believed that the disbalance between these two receptor-induced pathways determines the proangiogenic nature of TGF-ß (Lambert et al., 2016; Tosi et al., 2018; Fallah et al., 2019). It has been established that the TGF- 3 level in the vitreous is higher in patients with nAMD when compared to controls and selective inhibition of TGF- $\beta$ results in reduced neovascularisation, both decreasing TGF- $\beta$ action directly and lowering the up-regulation of VEGF (Zarranz-Ventura et al., 2013; Bai et al., 2014).

Pigment epithelium-derived factor. Pigment epitheliumderived factor (PEDF) acts as an antiangiogenic, neurotrophic and neuroprotective factor; in the eye it is produced mainly by RPE cells (Garcia-Garcia et al., 2017; Kersten et al., 2018). One of the main actions of PEDF is to inhibit the proliferation of endothelial cells, inducing selective apoptosis of RPE, and therefore, inhibiting the formation of retinal neovascularisation. Equal levels of PEDF and VEGF prevent the formation of neovascularisation. Significantly increased VEGF and decreased PEDF levels disassemble the homeostatic state of the retina and induce the formation of newly formed blood vessels. An increased VEGF/PEDF ratio has been established as an important risk factor for the formation of nAMD (Bhutto et al., 2006; Tong et al., 2006; Li et al., 2019). In a study performed on animals, elevated PEDF levels decreased neovascularisation significantly, uncovering PEDF as a potential treatment target (GarciaGarcia et al., 2017; Askou et al., 2019). A study showed that one month after receiving intravitreal treatment, significant reduction in VEGF and PEDF levels were observed, along with anatomical improvement of the macula, indicating that PEDF reacts on changes in VEGF levels (Ahn and Moon, 2009).

Thrombospondin 1. Thrombospondin 1 (TSP-1), similarly to PEDF, acts as an antiangiogenic factor and is produced mainly by RPE cells. TSP-1 has an essential role in the development of retinal vasculature, and therefore TSP-1 actions are targeted on limiting excessive formation of new blood vessels (Masli et al., 2014). TSP-1 occurs at significantly high levels in the aqueous humour in nAMD. Using animal models, it has been shown that TSP-1 reduces the amount of neovascularisation, but further research on humans is necessary (Farnoodian et al., 2017).

\section{CONCLUSIONS}

The up-regulation of proangiogenic factors is intensively restricted by antiangiogenic factors. Therefore, it is important for proangiogenic and antiangiogenic factors to be in a homeostatic state to prevent the progression of nAMD. Any deviation in the levels of angiogenic factors is potentially detectable in aqueous humour, indicating changes into the process of angiogenesis. Angiogenic factors could reveal an elevated risk for the development of nAMD, and could be used in monitoring of the retinal response to applied therapy and the retinal angiogenic state, before any structural changes could be detected. Angiogenic factors can be considered as potential biomarkers for nAMD, but further investigation is necessary.

\section{REFERENCES}

Ahn, J. K., Moon, H. J. (2009). Changes in aqueous vascular endothelial growth factor and pigment epithelium-derived factor after ranibizumab alone or combined with verteporfin for exudative age-related macular degeneration. Amer. J. Ophthalmol., 148, 718-724.

Anonymous (2001). Biomarkers and surrogate endpoints: Preferred definitions and conceptual framework. Clin. Pharmacol. Ther., 69, 89-95.

Askou, A. L., Alsing, S., Benckendorff, J. N. E., Holmgaard, A., Mikkelsen, J. G., Aagaard, L., Bek, T., Corydon, T. J. (2019). Suppression of choroidal neovascularization by AAV-based dual-acting antiangiogenic gene therapy. Mol. Ther. Nucl. Acids, 16, 38-50.

Bai, Y., Liang, S., Yu, W., Zhao, M., Huang, L., Zhao, M., Li, X. (2014). Semaphorin 3A blocks the formation of pathologic choroidal neovascularization induced by transforming growth factor beta. Mol. Vision, 20, 1258-1270.

Bakri, N. M., Ramachandran, V., Kee, H. F., Subrayan, V., Isa, H., Ngah, N. F., Mohamad, N. A., Mooi, C. S., Mun, C. Y., Ismail, P., Ismail, F., Sukiman, E. S., Sulaiman, W. A. W. (2018). Copy number variation in VEGF gene as a biomarker of susceptibility to age-related macular degeneration. Egypt. J. Med. Hum. Gen., 19, 207-213.

Balne, P. K., Agrawal, R., Bijin, V., Lee, B., Ghosh, A., Sethy, S., Agrawal, M., Narayanan, R., Connolly, J. (2018). Dataset of plasma and aqueous humor cytokine profiles in patients with exudative age related macular degeneration and polypoidal choroidal vasculopathy. Data in Brief, 19, 1570-1573.

Berg, K., Pedersen, T. R., Sandvik, L., Bragadottir, R. (2015). Comparison of ranibizumab and bevacizumab for neovascular age-related macular degeneration according to LUCAS tret-and-extend protocol. Ophthalmology, 122, 146-152.

Betsholtz, C. (2004). Insight into the physiological functions of PDGF through genetic studies in mice. Cytokine Growth Factor Rev., 15, 215-228.

Bhutto, I. A., McLeod, D. S., Hasegawa, T., Kim, S. Y., Merges, C., Tong, P., Lutty, G. A. (2006). Pigment epithelium-derived factor (PEDF) and vascular endothelial growth factor (VEGF) in aged human choroid and eyes with age-related macular degeneration. Exp. Eye Res., 82 (1), 99-110.

Cabral, T., Lima, L. H., Mello, L. G. M., Polido, J., Correa, E. P., Oshima, A., Duong, J., Serracarbassa, P., Regatieri, C. V., Mahajan, V. B., Belfort, R. J. (2018). Bevacizumab injection in patients with neovascular age-related macular degeneration increases angiogenic biomarkers. Ophthalm. Retina, 2 (1), 31-37. 
Castellino, N., Longo, A., Avitabile, T., Russo, A., Fallico, M., Bonfiglio, V., Toro, M. D., Rejdak, R., Nowomiejska, K., Murabito, P., Furino, C., Reibaldi, M. (2018). Circulating insulin-like growth factor-1: A new clue in the pathogenesis of age-related macular degeneration. Aging, 10 (12), 4241-4247.

Chakravarthy, U., Bailey, C., Brown, D., Campochiaro, P., Chittum, M., Csaky, K., Tufail, A., Yates, P., Cech, P., Giraudon, M., Delmar, P., Szczesny, P., Sahni, J., Boulay, A., Nagel, S., Fürst-Recktenwald, S., Schwab, D. (2017). Phase I trial of anti-vascular endothelial growth factor/anti-angiopoietin 2 bispecific antibody RG7716 for neovascular age-related macular degeneration. Ophthalmol. Retina, 1, 474-485.

Chen, L. J., Ma, L., Chu, W. K., Lai, T. Y. Y., Chen, H., Brelen, M. E., Rong, S. S., Young, A. L., Tam, P. O. S., Zhang, M., Pang, C. P. (2016). Identification of PGF as a new gene for neovascular age-related macular degeneration in a Chinese population. Invest. Ophthalmol. Vis. Sci., 57, 1714-1720.

Chiu, C. J., Conley, Y. P., Gorin, M. B., Gensler, G., Lai, C. Q., Shang, F., Taylor, A. (2011). Associations between genetic polymorphisms of insulin-like growth factor axis genes and risk for age-related macular degeneration. Invest. Ophthalmol. Vis. Sci., 52, 9099-9107.

Clemons, T. E., Milton, R. C., Klein, R., Seddon, J. M., Ferris, $3^{\text {rd }}$ F. L. (2005). Risk factors for the incidence of advanced age-related macular degeneration in the age-related eye disease study (AREDS). AREDS report No. 19. Ophthalmology, 112, 533-539.

Clijn, J. M., Buitendijk, G. H. S., Prokofyeva, E., Alves, D., Cachulo, M. L., Khawaja, A. P., Cougnard-Gregoire, A., Merle, B. M. J., Korb, C., Erke, M. G. et al. (2017). Prevalence of age-related macular degeneration in Europe. Ophthalmology, 124 (12), 1753-1763.

Evans, J. R., Fletcher, A. E., Wormald, R. P. (2004). Age-related macular degeneration causing visual impairment in people 75 years or older in Britain: An add-on study to the medical research council trial of assessment and management of older people in the community. Ophthalmology, 111, 513-517.

Fallah, A., Sadeghinia, A., Kahroba, H., Samadi, A., Heidari, H. R., Bradaran, B., Zeinali, S., Molavi, O. (2019). Therapeutic targeting of angiogenesis molecular pathways in angiogenesis-dependent diseases. Biomed. Pharmacother., 110, 775-785.

Farnoodian, M., Wang, S., Dietz, J., Nickells, R. W., Sorenson, C. M., Sheibani, N. (2017). Negative regulators of angiogenesis: Important targets for treatment of exudative AMD. Clin. Sci. (Lond), 131 (15), 1763-1780.

Garcia-Garcia, L., Recalde, S., Hernandez, M., Bezunartea, J., Rodriguez-Madoz, J. R., Johnen, S., Diarra, S., Marie, C., Izsvak, Z., Ivics, Z. et al. (2017). Long-term PEDF release in rat iris and retinal epithelial cells after sleeping beauty transposon-mediated gene delivery. Mol. Ther. Nucl. Acids, 9, 1-11.

Grassmann, F., Friedrich, U., Fauser, S., Schick, T., Milenkovic, A., Schulz, H. L., von Strachqitz, C. N., Bettecken, T., Lichtner, P., Meitinger, T., Arend, N., Wolf, A., Haritoglou, C., Rudolph, G., Chakravarthy, U. (2015). A candidate gene association study identifies DAPL1 as a female-specific susceptibility locus for age-related macular degeneration (AMD). NeuroMol. Med., 17 (2), 111-120.

Gu, X., Yu, X., Dai, H. (2014). Intravitreal injection of ranibizumab for treatment of age-related macular degeneration: Effects on serum VEGF concentration. Curr. Eye Res., 39 (5), 518-521.

Gupta, D., Gupta, V., Singh, V., Chawla, S., Parveen, F., Agrawal, S., Phadke, S. R. (2014). Study of polymorphisms in CX3CR1, PLEKHA1 and VEGF genes as risk factors for age-related macular degeneration in Indian patients. Arch. Med. Res., 45, 489-494.

Huber, M., Wachtlin, J. (2012). Vitreous levels of proteins implicated in angiogenesis are modulated in patients with retinal or choroidal neovascularization. Ophthalmologica, 228, 188-193.

Huo, X., Li, Y., Jiang, Y., Sun, X., Gu, L., Guo, W., Sun, D. (2015). Inhibition of ocular neovascularization by co-inhibition of VEGF-A and PLGF. Cell Physiol. Biochem., 35, 1787-1796.
Jaffe, G. J., Ciulla, T. A., Ciardella, A. P., Devin, F., Dugel, P. U., Eandi, C. M., Masonson, H., Mones, J., Pearlman, J. A., Quaranta-El Maftouhi, M., Ricci, F., Westby, K., Patel, S. C. (2017). Dual antagonism of PDGF and VEGF in neovascular age-related macular degeneration. Ophthalmology, 124, 224-234.

Kazlauskas, A. (2017). PDGFs and their receptors. Gene, 614, 1-7.

Kersten, E., Paun, C. C., Schellevis, R. L., Hoyng, C. B., Delcourt, C., Lengyel, I., Peto, T., Ueffing, M., Klaver, C. C. W., Dammeier, S., den Hollander, A. I., de Jong, E. K. (2018). Systemic and ocular fluid compunds as potential biomarkers in age-related macular degeneration. Surv. Ophthalmol., 63, 9-39.

Kim, J., Park, J. R., Choi, J., Park, I., Hwang, Y., Bae, H., Kim, Y., Choi, W., Yang, J. M., Han, S. et al. (2019). Tie2 activation promotes choriocapillary regeneration for alleviating neovascular age-related macular degeneration. Sci. Adv., 5, eaau6732.

Kinnunen, K., Petrovski, G., Moe, M. C., Berta, A., Kaarniranta, K. (2012). Molecular mechanisms of retinal pigment epithelium damage and development of age-related macular degeneration. Acta Ophthalmol., 90, 299-309.

Lambert, N. C., El Shelmani, H., Singh, M. K., Mansergh, F. C., Wride, M. A., Padilla, M., Keegan, D., Hogg, R. E., Ambati, B. K. (2016). Risk factors and biomarkers of age-related macular degeneration. Progr. Retinal Eye Res., 54, 64-102.

Lambert, N. G., Zhang, X., Rai, R. R., Uehara, H., Choi, S., Carroll, L. S., Das, S. K., Cahoon, J. M., Kirk, B. H., Bentley, B. M., Ambati, B. K (2016). Subretinal AAV2.COMP-Ang1 suppresses choroidal neovascularization and vascular endothelial growth factor in a murine model of age-related macular degeneration. Exper. Eye Rese., 145, 248-257.

Li, R., Du, J. H., Yao, G. M., Yao, Y., Zhang, J. (2019). Autophagy: A new mechanism for regulating VEGF and PEDF expression in retinal pigment epithelium cells. Int. J. Ophthalmol., 12 (4), 557-562.

Masli, S., Sheibani, N., Cursiefen, C., Zieske, J. (2014). Matricellular protein thrombospondin: Influence on ocular angiogenesis, wound healing and immuneregulation. Curr. Eye Res., 39 (8), 759-774.

Mesquita, J., Castro-de-Sousa, J. P., Vaz-Pereira, S., Neves, A., Passarinha, L. A., Tomaz, C. T. (2018). Vascular endothelial growth factors and placenta growth factor in retinal vasculopathies: Current research and future perspectives. Cytokine Growth Factor Rev., 39, 102-115.

Mitchell, P., Liew, G., Gopinath, B., Wong, T. Y. (2018). Age-related macular degeneration. Lancet, 392, 1147-1159.

Ng, D. S., Yip, Y. W., Bakthavatsalam, M., Chen, L. J., Ng, T. K., Lai, T. Y., Pang, C. P., Brelen, M. E. (2017). Elevated angiopoietin 2 in aqueous of patients with neovascular age related macular degeneration correlates with disease severity at presentation. Sci. Rep., 27 (7), 45081.

Ng, E. W. M., Adamis, A. P. (2005). Targeting angiogenesis, the underlying disorder in neovascular age-related macular degeneration. Can. J. Ophthalmol., 40, 352-368.

Owen, C. G., Jarrar, Z., Wormald, R., Cook, D. G., Fletcher, A. E., Rudnicka, A. R. (2012). The estimated prevalence and incidence of late stage age related macular degeneration in the UK. Brit. J. Ophthalmol., 96, 752-756.

Rakic, J. M., Lambert, V., Devy, L., Luttun, A., Carmeliet, P., Claes, C., Nguyen, L., Foidart, J. M., Noèl, A., Munaut, C. (2003). Placental growth factor, a member of the VEGF family, contributes to the development of choroidal neovascularization. Invest. Ophthalmol. Vis. Sci., 44, 3186-3193.

Rastogi, N., Smith, T. (2016). Association of age-related macular degeneration and reticular macular disease with cardiovascular disease. Surv. Ophthalmol., 61 (4), 422-433.

Rein, D. B., Wittenborn, J. S., Zhang, X., Honeycutt, A. A., Lesesne, S. B., Saaddine, J. (2009). Vision health cost-effectiveness study group. Forecasting age-related macular degeneration through the year 2050. Arch. Ophthalmol., 127 (4), 533-540.

Rosenthal, R., Wohlleben, H., Malek, G., Schlichting, L., Thieme, H., Bowes Rickman, C., Strauss, O. (2004). Insulin-like growth factor-1 contributes to 
neovascularization in age-related macular degeneration. Biochem. Biophys. Res. Commun., 323, 1203-1208.

Sall, J. W., Klisovic, D. D., O’Dorisio, M. S., Katz, S. E. (2004). Somatostatin inhibits IGF-1 mediated induction of VEGF in human retinal pigment epithelial cells. Exper. Eye Res., 79 (4), 465-476.

Storkebaum, E., Carmeliet, P. (2004). VEGF: A critical player in neurodegeneration. J. Clin. Invest., 113 (1), 14-18.

Tamhane, M., Cabrera-Ghayouri, S., Abelian, G., Viswanath, V. (2019). Review of biomarkers in ocular matrices: Challenges and opportunities. Pharm. Res., 36, 40.

Tong, J. P., Chan, W. M., Liu, D. T. L., Lai, T. Y. Y., Choy, K. W., Pang, C. P., Lam, D. S. C. (2006). Aqueous humor levels of vascular endothelial growth factor and pigment epithelium-derived factor in polypoidal choroidal vasculopathy and choroidal neovascularization. Amer. J. Ophthalmol., 141, 456-462.

Tosi, G. M., Orlandini, M., Galvagni, F. (2018). The controversial role of TGF- $\beta$ in neovascular age-related macular degeneration pathogenesis. Int. J. Mol. Sci., 19, 3363.

Tsai, D. C., Charng, M. J., Lee, F. L., Hsu, W. M., Chen, S. J. (2006). Different plasma levels of vascular endothelial growth factor and nitric oxide be- tween patients with choroidal and retinal neovascularization. Ophthalmologica, 220 (4), 246-251.

Van Bergen, T., Etienne, I., Cunningham, F., Moons, L., Schlingemann, R. O., Feyen, J. H. M., Stitt, A. W. (2019). The role of placental growth factor (PIGF) and its receptor system in retinal vascular diseases. Progr. Retinal Eye Res., 69, 116-136.

van Lookeren Campagne, M., LeCouter, J., Yaspan, B. L., Ye, W. (2014). Mechanisms of age-related macular degeneration and therapeutic opportunities. J. Pathol., 232, 151-164.

Wong, W. L., Su, X., Li, X., Cheung, C. M., Klein, R., Cheng, C. Y., Wong, T. Y. (2014). Global prevalence of age-related macular degeneration and disease burden projection for 2020 and 2040: A systematic review and meta-analysis. Lancet Glob. Heal, 2, e106-e115.

Zarranz-Ventura, J., Fernandez-Robredo, P., Recalde, S., Salinas-Alaman, A., Borras-Cuesta, F., Dotor, J., Garcia-Layana, A. (2013). Transforming growth factor-beta inhibition reduces progression of early choroidal neovascularization lesions in rats: $\mathrm{P} 17$ and P144 peptides. PLOS ONE, 8 (5), e65434.

Zehetner, C., Kirchmair, R., Neururer, S. B., Kralinger, M. T., Bechrakis, N. E., Kieselbach, G. F. (2014). Systemic upregulation of PDGF-B in patients with neovascular AMD. Invest. Ophthalmol .Vis. Sci., 55, 337-344.

Received 10 September 2019

Accepted in the final form 27 October 2019

\section{ACS ANGIOGĒNO FAKTORU LOMA NEOVASKULĀRAS VECUMA MĀKULAS DEG̣ENERĀCIJAS ATTĪSTĪBĀ}

Vecuma mākulas deǵenerācija (VMD) ir progresējoša, deǵeneratīva acs slimība. Neovaskulāra vecuma mākulas deǵenerācija (nVMD) ir VMD beigu stadija, kurai raksturīga anormāla jaunveidotu asinsvadu augšana dzīslenē, kas parasti ir saistīta ar škidruma uzkrāšanos tīklenē vai tīklenes saasiņojumiem, tīklenes epitēlija atslān,ošanos, cieto eksudātu, vai subretinālu rētu veidošanos. Angioğenēzes procesu regulē acs angiogēnie faktori, uz kuriem iedarbojoties kā uz terapijas objektu, ir radīta iespēja izstrādāt dažādus ārstēšanas veidus nVMD gadījumā. Šī apskata mērkis ir apkopot pieejamo informāciju par visbiežāk identificētajiem acs angiogēnajiem faktoriem, atklājot to lomu nVMD patoğenēzē un izvērtējot to pielietošanas iespējas kā slimības identifikācijas un ārstēšanas procesa biomarķieriem. 